\title{
The Role of the White House in the Establishment of a Governmental Radio Monopoly in the United States. The Case of the Radio Corporation of America.
}

\author{
Alejandro Casasempere García ${ }^{(1)}$ and Antonio Pérez Yuste ${ }^{(2)}$ \\ ${ }^{(1)}$ Institute of Electrical and Electronics Engineers (IEEE), New Brunswick, NJ, 08901 USA \\ ${ }^{(2)}$ Technical University of Madrid (UPM), Madrid, 28040, Spain
}

\begin{abstract}
This research work achieves an understanding of the causes behind the decision of the White House and the US Department of the Navy to take total control of Marconi's interests in the USA, revealing the role played by the principal people involved in the creation of a virtual governmental radio monopoly.

This study also clarifies how this governmental radio monopoly was conceived, concluding with the establishment of Radio Corporation of America (RCA) as a privately owned de facto American monopoly in radio communications, under the control of the US Department of the Navy and the White House, which facilitated patent pools permitting the telecommunications industry to emerge in the United States.
\end{abstract}

Index Terms - American Marconi, British Marconi, Nally, Radio Broadcasting, RCA, Sarnoff.

\section{INTRODUCTION}

Due to its tremendous influence on our society, this paper for the History of Telecommunication Conference, HISTELCON 2010, treats the political as well as the social, economic, cultural, business and technical dimensions of what has been one of the major discoveries and technological advances in telecommunications through history, the radio, whose ubiquity made it the most influential of all the mass media before television and internet.

In the development of any great enterprise, vision and imagination are generally the elemental factors that shape into consciousness the original concept of what is to follow. Courage and aggressive attention to mechanical details and executive requirements go hand in hand with vision and imagination in making the development of the enterprise staple. The individuals possessing all these attributes are hard to find and the organization is indeed fortunate if among a large number of the staff these characteristics are available in some degree or other. When, however, one individual possesses, not only vision and imagination, but the ability to undertake the working out of the practical details of the enterprise and the experience and talent to manage the executive departments as well, the organization is not only fortunate, it is lifted into an extraordinary position.

With regard to the topic of this paper, this man was, in essence, Edward Julian Nally, who, against other authors' opinions like Archer that emphasizes other American prominent people like Owen D. Young or Rear Admiral
Stanford Caldwell Hooper, led the establishment of Radio Corporation of America (RCA). [1]

\section{BACKGROUND}

At the beginning of the story, Marconi's Wireless Telegraph Company, Ltd., of London, England, namely the British Marconi, was established on July $29^{\text {th }}, 1897$, being the first private-owned company in the field of radio communications.

Since its foundation, the British Marconi had the intention to arrange a worldwide wireless system, organizing subsidiaries acting as tributaries or feeders to the parent company in many countries.

The foundation of RCA cannot be understood without the Marconi Wireless Telegraph Company of America, namely the American Marconi, which was established by the British Marconi in Trenton under the laws of the State of New Jersey, USA, on November $22^{\text {nd }}, 1899$. That action involved a capital of $\$ 10,000,000$ distributed into two million shares at \$5 each. Seven million dollars were subscribed in cash at par and the other three were issued to Guglielmo Marchese Marconi for the patents. [2]

At that time, the stock distribution reflected that more than fifty per cent of the shares available were owned by English interests. In 1912, the assets of the United Wireless Telegraph Company, namely the Lee De Forest Company, were bought out for $\$ 700,000$ in Marconi stock, which partly accounted for the American stockholders.

There were out of the 22,000 American Marconi stockholders a majority placed in America, although much more than a half of the holdings were in foreign hands. In fact, Nally was unable to give to the United States Shipping Board an affidavit confirming that at least the fifty-one per cent of the stock was owned by American citizens in 1919.

The first contracts between the British Marconi and the American Marconi were on April $18^{\text {th }}, 1902$, through which the British Marconi granted the American Marconi the indispensable United States, Philippine and Cuban patents for wireless operation, agreeing to establish a jointly operated circuit to which each should be loyal and against which neither should compete. The agreement also obligated the British Marconi to furnish technical and manufacturing information and to convey to the American Marconi the 
station at Cape Cod, Massachusetts. For such patent rights and the station the British Marconi received \$3,382,000 par value of capital stock $(33,820$ shares) of the American Marconi and $\$ 75,000$ in cash.

\section{ADVERSE LEGISLATION}

As soon as World War I was declared, the American Marconi placed all its facilities at the US Government's disposal, which took over the high-power stations as well as the coastal stations for marine service on April $7^{\text {th }}, 1917$. Even so, the military operations of war brought radio to a high development zenith and it could be stated that the art of radio was really born during the Great War.

The New Brunswick station was reconstructed by installing the Alexanderson continuous wave transmitting system. Furthermore, the Belmar receiving station was also reconstructed by the US Department of the Navy by combining patents of all the existing companies including John Ambrose Fleming's vacuum tubes, Edwin Howard Armstrong's regenerative amplification, Reginald Aubrey Fessenden's heterodyne selection for continuous wave reception and Roy Alexander Weagant's static eliminator antennas. The problem was that each of these great developments in radio was owned by a different company. Separately, no one concern could possibly operate a radio circuit legally, without infringing patent rights.

\section{A. South America}

Nally went to the US Department of State in 1915 and he asked for its support to obtain the necessary concessions for wireless expansion in some South American countries. They refused the request on account of the known British connection in the American Marconi. Meanwhile, Federal Telegraph \& Telephone Company of California had a concession in Argentina and it also had the Poulsen arc patents, which, it was hoped, might be used for long distance wireless communication. On May $15^{\text {th }}, 1918$, those patents were subsequently purchased for $\$ 1,600,000$ by the US Department of the Navy, in order to prevent the American Marconi company from obtaining continuous wave technology.

At that juncture, Nally asked the US Department of State and the Department of the Navy if they would support the new Pan-American Wireless Telegraph \& Telephone Company, jointly owned by the British Marconi, which was founded on February $9^{\text {th }}, 1917$, for communication service between North, Central and South America. It was capitalized for $\$ 350,000$ preferred, 3,500 shares par value $\$ 100$, none issued, and 50,000 shares common, no par, all issued. The American Marconi and the British Marconi had three eights each in proportion and the Federal Telegraph \& Telephone Company the other two eights. Both departments withdrew their approval and they opposed the whole plan for South American development and expansion, threatening more adverse legislation and making it impossible to obtain any concessions or financing sources due to the fact that no alien owned company would be given any privileges or rights as well as any sanction or support by the US Government.

Likewise, the patents of the American Marconi and the Federal Telegraph companies were not enough to cover all the necessities which the South American traffic required. Consequently, both the British and the American Marconi's holdings in the Pan-American company were conveyed to RCA and Pan-American Wireless Telegraph \& Telephone Company was ultimately dissolved to enter the agreements with the AEFG Consortium, later renamed Commercial Radio International Committee (CRIC), in which American, English, French and German interests were represented. [3]

\section{B. Competitors}

The business competitors of the wireless ship-to-shore service on the Atlantic Coast were several companies such as Independent Wireless Telegraph Company, Shipowners' Radio Service Company, Cutting \& Washington Company, International Radio Telegraph Company and United Fruit Company with its subsidiaries Tropical Radio Telegraph Company and Wireless Specialty Apparatus Company. On the Pacific Coast there were others like Federal Telegraph \& Telephone Company and Kilbourne \& Clarke Manufacturing Company, which was a subsidiary of Shipowners' Radio Service Company.

The business competitors in the manufacturing field were De Forest Radio Telegraph \& Telephone Company, Federal Telegraph \& Telephone Company, Wireless Specialty Apparatus Company, General Electric Company (GE), Western Electric Company, which was a subsidiary of AT\&T, and Westinghouse Electric \& Manufacturing Company, but these latter three were not able to manufacture except for the US Government because of the patent laws.

\section{FORMATION OF RCA}

Early negotiations between GE and Marconi Wireless Telegraph Company took place in June of 1915 between Sidney St. John Steadman, representing the American company, and Guglielmo M. Marconi, representing the British one, who offered to buy $5,000 \mathrm{KW}$. of alternators yearly at a cost of $\$ 3,200,000$. However, when World War I broke out, Marconi returned to Italy on May $22^{\text {nd }}, 1915$, and then England took over the operations.

On May $10^{\text {th }}, 1917$, immediately after the United States entered into the War, GE notified Guglielmo M. Marconi that all understandings were cancelled.

Nonetheless, in order to try and test it in a real operating wireless station, the GE installed a $50 \mathrm{KW}$. Alexanderson alternator at the New Brunswick station at its own expense, which was subsequently purchased by the American Marconi. When the US Navy took over the New Brunswick station they found that alternator running and asked for a $200 \mathrm{KW}$. similar 
machine. GE installed that new Alexanderson alternator, which was later paid for by the American Marconi. Therefore, the New Brunswick station was remodelled and a whole Alexanderson system was installed, carrying the bulk of the communications with Europe from June 1918 to the return of the station by the US Navy operation on March $1^{\text {st }}, 1920$.

The third stage in negotiations with GE began between February and March of 1919, when Nally asked for exclusive rights for the Alexanderson transmitting system. In fact, a tentative agreement for twenty-four alternators existed, fourteen for the American Marconi and the other ten for the British Marconi, at a cost of $\$ 127,000$ a piece. GE asked for an extra honorarium, which had been agreed as one million dollars in lieu of intellectual royalty.

The contract was about to be closed between GE and the American Marconi when, once again, the President of the USA Thomas Woodrow Wilson, the Secretary of the Navy Josephus Daniels, the Assistant Secretary of the Navy Franklin Delano Roosevelt, Rear Admiral William Hannum Grubb Bullard, Commander Stanford C. Hooper and other Officials, through the White House and its executive branches, came on the scene.

The US Government was procuring the adoption of the constitutional provision to make the wireless a governmental monopoly. However, in keeping with the traditional American relation between state and economy, the national wireless system was to be privately owned and operated. Thus, when they realized that the then Republican US Congress, consisting of the House of Representatives and the Senate, would not accept the nationalization for retaining the governmental radio monopoly during times of peace, President Wilson and the Secretary of the Navy Daniels sought another option to achieve their objective.

Hence, on April $5^{\text {th }}$, 1919, Secretary Daniels sent Rear Admiral H. G. Bullard, the then Director of Communications of the United States Navy, and Commander Sanford C. Hooper, Chief of the Radio Division of the Bureau of Steam Engineering, to interfere with the arrangements asking GE to break off any negotiations with the Marconi companies and urging them not to sell the alternators. Wielding patriotic reasons, they suggested that the first basis for clearing up the unlawful patent situation would be the formation of an American radio company, not affiliated with any concern under foreign jurisdiction. Of course, the US Government would try to secure a commercial monopoly of long-distance radio communications giving GE the use of all its radio patents, receiving in return a free license under all GE patents for governmental operation. [4]

After the strange business shift of GE towards accepting the US Navy behests, a new American company, backed by the US Government and supported by GE, would destroy all the value of the investment of thousands of stockholders in the American Marconi by putting it out of the market.

Nally then saw Rear Admiral William H. G. Bullard and Commander S. C. Hooper, who told him that the US
Department of the Navy wished American citizens to control the wireless and that the US Government intended to promote an American system which would communicate directly with all foreign countries. In fact, the US Government desired to establish the Wireless Monroe Doctrine, thus creating a $100 \%$ American system of radio communications through which the United States of America could directly communicate with other nations free from intermediaries. Apart from national security concerns and intelligence service reasons, that would avoid censorship, espionage and leakage. In fact, US Officials during the War discovered the enormous strategic value of international telecommunications, which blends military, diplomatic, technology and business history.

In relation to that issue, a discrepancy should be pointed out concerning to George H. Clark's book "The Formation of the Radio Corporation of America", where the author remarks on the special role played by Rear Admiral Stanford C. Hooper in the formation of the RCA, which was able to pass the US Navy censorship. Clark himself confesses in a letter sent to Nally, which was found in Princeton University. Direct quotation: "I ask this in the name of future readers, who will want some day to know the truth". [5]

While not all of the Board of Directors of the American Marconi entirely agreed with Nally's views and recommendations at that time, he went ahead with the negotiations having many talks with Owen D. Young, then Vice President of GE, as well as with several prominent and influential men in financial circles of New York. Owen D. Young confirmed that the negotiations for the Alexanderson alternators must necessarily terminate in view of the US Government request. However, despite the fact that GE had the Alexanderson patents, GE had no radio stations and no experience in the wireless communication service. On the contrary, notwithstanding its patents and equipment were insufficient to properly conduct the transoceanic long-distance service, the American Marconi had that experience and the indispensable radio stations.

In that case, Edward J. Nally asked Owen D. Young whether the US Government would object if GE bought out Marconi Wireless Telegraph Company of America or not, pointing out that, although GE had important patents, it would be impossible for it to establish reliable and commercially viable wireless communications without other indispensable patents such as Fleming's valve as a vacuum tube diode, Armstrong's feedback, De Forest's oscillator, and Weagant's static eliminator antenna. While the federal executive departments were giving the matter serious consideration, Nally wrote to Godfrey C. Isaacs, then Managing Director of Marconi Wireless Telegraph Company, Ltd., giving the whole picture of the situation as it was and supplying the reasons to convince the British Marconi of the hopelessness of endeavouring to hold stock in the American Marconi.

Besides, as soon as a preliminary understanding had been reached between Owen D. Young and Edward J. Nally, Albert G. Davis, then Head of the Patent Department of GE, went to 
Washington, DC, and asked the US Navy Officials if the proposed set-up would satisfy the governmental desires for the considered necessary American owned radio system. Providentially, it would. However, talking about the name of the new company, the word "Marconi" would have to be dropped out of consideration to the US Government's objections. Nally firstly thought of "American Communication Company", but when he realized that the Atlantic Communication Company already existed, he changed to the definitive "Radio Corporation of America". [6]

By the time it was in effect an agreement dated March $3^{\text {rd }}$, 1897, between GE and British Thomson-Houston Company (BTH), by which GE granted BTH exclusive rights under its UK patents and BTH granted GE the same under its US patents. Consequently, GE would grant the new RCA an exclusive license to use and sell apparatus for radio purposes under its patents of all countries, so it seemed apparent that the British Marconi would insist upon the rights under UK patents to use the Alexanderson alternator and other GE inventions as a condition prior to selling its holdings in the American Marconi. However, in view of that agreement between GE and $\mathrm{BTH}, \mathrm{GE}$ could not grant any rights under its UK patents to anyone other than BTH without the consent of the latter.

Edward J. Nally and Albert G. Davis proceeded to London on August 1919 for the dual purpose of obtaining said consent from BTH and to negotiate with Godfrey C. Isaacs, urging him to take action concerning the sale of the British Marconi's holdings in the American Marconi on a reasonable basis. Isaacs considered the effect which the formation of the new American company would have on the connecting arrangements with foreign stations erected and operated by the British Marconi and its affiliated companies in France, Spain, etc. GE, because of its organization in France, England and other countries, might be able to secure the concessions from those countries for the erection of independent stations which would cut out the large stations belonging to the British Marconi. If an arrangement agreeable to the US Government could be entered into by which the American stations under the new auspices would continue to connect with the existing or future stations belonging to the English, French and Spanish Marconi companies, that would be a powerful argument in favour of the British Marconi disposing of its holdings in the American Marconi for a sum exceeding $\$ 2,000,000$.

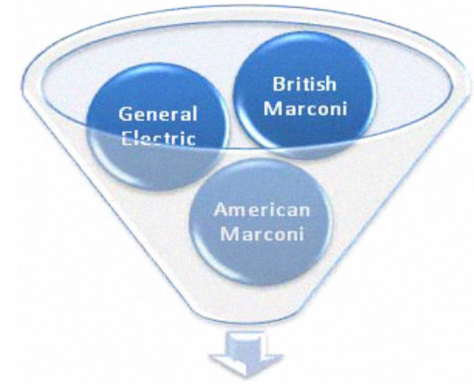

Radio Corporation of America

Fig. 1. Foundation of RCA
After long efforts in the form of conferences, organization charts, financial arrangements, etc., they finally succeeded in both objectives and an agreement in principle was reached in October. Then, on October $17^{\text {th }}, 1919$, GE founded RCA under the laws of the State of Delaware, USA, buying out the British Marconi stock in the American Marconi.

\section{CROSS-License AgREEMENTS TOWARDS MONOPOLY}

On October $22^{\text {nd }}, 1919$, a preliminary agreement between Marconi Wireless Telegraph Company of America and RCA took place and about a month later, on November $20^{\text {th }}, 1919$, the Main Agreement between Marconi Wireless Telegraph Company of America and RCA was reached.

The same day, GE and RCA signed the License Agreement A, granting to RCA the exclusive license to use and sell apparatus for radio purposes under all of GE's patent rights. Since such rights included the US patents of BTH, RCA thus acquired through GE a license under BTH's US patents, but not UK patents. The license was to continue to January $1^{\text {st }}$, 1945. Radio therefore remained a commercially dominated medium, but subject to governmental regulation under the Federal Radio Commission, forerunner of the Federal Communications Commission (FCC), which assumed regulatory control over all radio, telephone, telegraph and cables. Rear Admiral William H. G. Bullard was the designated Chairman of its board.

The agreement between RCA, the British Marconi and BTH was executed the next day on November $21^{\text {st }}, 1919$. It was to continue until January $1^{\text {st }}, 1945$, too. RCA granted the British Marconi a license under RCA's British Commonwealth countries patents for radio purposes and BTH joined in that grant in respect of all UK patents for radio purposes which it had received or during the term of the agreement it would receive from GE. BTH in turn received a license for non-radio uses of RCA's UK patents for radio purposes.

License Agreement A, as subsequently amended, had been superseded by Agreement A-1 and supplements. As a result, RCA's licenses under GE patent rights had been extended another ten years to January $1^{\text {st }}, 1955$, and greatly broadened in scope. They included, through GE, a license under BTH's US patents.

RCA was then in the position of receiving a license under US patents of BTH inventions to January $1^{\text {st }}, 1955$, whereas BTH's rights under UK patents of RCA inventions were limited to inventions made before January $1^{\text {st }}$, 1945. In addition, BTH's rights under RCA inventions were of a different character from those received by RCA under BTH inventions, since the $\mathrm{BTH}$ received a license only for nonradio uses of RCA's patents for radio purposes and RCA received a license for radio purposes plus the many non-radio purposes for which it had the rights as provided for in the License Agreement A-1 and supplements. Stated otherwise, BTH had no rights under RCA's patents for anything other than radio purposes, such as its patents for electronic 
apparatus for power purposes, controlled gaseous tubes, gaseous rectifier tubes, pool tubes, facsimile duplicating apparatus, radiofrequency heating apparatus, electron microscopes, diffraction cameras and electronic sewing machines.

It is interesting to note that, in addition to the business equities, the legal situation also favoured RCA in any approach to a new agreement. The basis for this statement has been indicated above. It includes among other points the fact that RCA continued to have rights of new inventions of the British Marconi and BTH, while those companies had no rights to any inventions of RCA since January $1^{\text {st }}, 1945$. The British Marconi was obligated to provide technical and manufacturing information to RCA, while RCA had no such obligation to the British Marconi and the rights which the British Marconi had under patents for toll communication apparatus were lost as a result of the nationalization of the toll communication business in the UK. By the end of the 1920's the British Marconi had ceased to be an operating communications company and by early in the 1930's BTH had become in effect a department of a larger unit which could confine the operations of BTH in such manner as suited its purpose. In contrast, RCA had developed from an infant business to the outstanding radio organization in the world, preeminent in research, communication, manufacturing and broadcasting.

On the other hand, if the American public were to be provided with the best possible radio apparatus and service, besides the engineering improvements made in the antennas, it was necessary to avoid any patent deadlock. Suggestions from the US Department of the Navy brought about a complete interchange of patent rights between the warring holders of the most important patents.

In essence, by means of the necessary cross-licensing agreements made during 1920 and 1921, the GE, with its Alexanderson alternator, the American Telephone and Telegraph Company (AT\&T), with its rights on the De Forest's patents on vacuum tubes including the use in amplifiers, the Westinghouse Electric \& Manufacturing Company with its possession of the Fessenden and Armstrong's patents involving the heterodyne, regenerations and feedback, the United Fruit Company with Pickard's patents on crystals and others detectors, the RCA with its fundamental Guglielmo M. Marconi's patents, the Sir Oliver Joseph Lodge tuning patent, the Fleming's valve patent and the Weagant's static eliminator patent, as well as its knowledge of radio manufacturing and operation, joined forces to provide, for the first time in history, a completely authorized workable radio system.

In 1921, as a result of those mergers and cross-licensing agreements, the RCA either owned or possessed license rights to use more than two thousand patents.

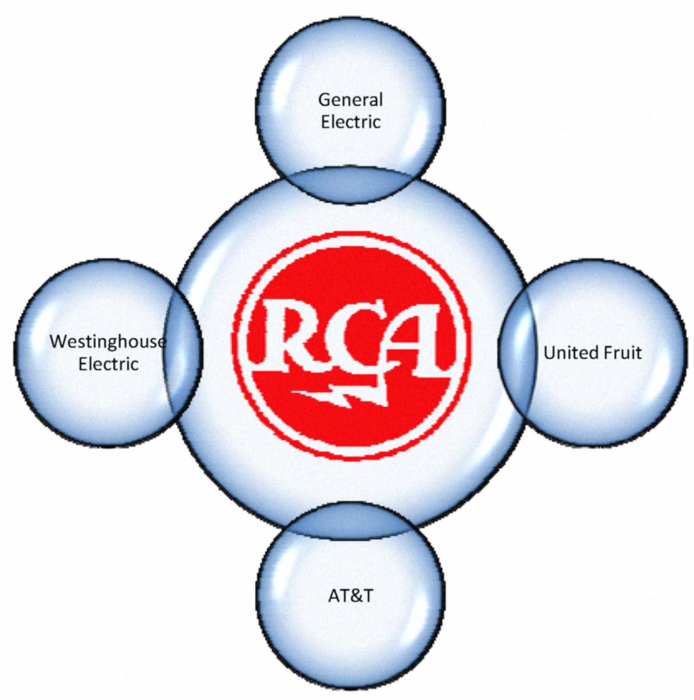

Fig. 2. Cross-License Agreements.

These agreements included the most important patents of that time and provided the RCA and its affiliated companies with a monopoly in the manufacture and sale of radio equipment, which was granted due to the fact that RCA was selling equipment manufactured by GE (60\%) and Westinghouse (40\%), while AT\&T had the monopoly in transmitters. What a coincidence, they were the very same people who were members of the Board of Directors of RCA, four of the old American Marconi, four from GE, three from Westinghouse, two from AT\&T and one from United Fruit.

Moreover, with the agreements with the French Compagnie Générale de Télégraphie Sans Fil, RCA was placed in a peculiarly strong position to carry on the great work for which it had been established: a powerful American worldwide radio communications system by securing a virtual monopoly over the latest technology.

The first comprehensive availability of patents had consequently been created and David Sarnoff was largely instrumental in achieving that, whose efforts stimulated growth in manufacturing and broadcasting, in worldwide communications, marine and aviation radio, in television, radar and electronics.

What is more, Nally signed traffic agreements with the various radio systems of, for instance, France, Great Britain, Germany, Japan, Poland, Italy, Norway, Sweden, the Netherlands, Brazil and Argentina. Those agreements specified the correspondent stations, their frequencies, hours and division of revenues and also included the cross-licensing of patents. A virtual monopoly had been arranged.

Rear Admiral William H. G. Bullard suggested a provision for retaining the control of the radio art in hands of American citizens by making foreigners ineligible as officers or directors of the new corporation by restricting the alien-held voting stock to $20 \%$, by authorizing the Secretary of the Navy to challenge any votes and by the appointment of a US 
Government representative to sit on the Board of Directors of RCA, who, as it could not be otherwise, was finally Rear Admiral William H. G. Bullard. This was approved by President Woodrow Wilson on January $14^{\text {th }}, 1920$.

The first meeting of the Board of Directors took place on December $3^{\text {rd }}$, 1919: [7]

\section{TABLE I}

FIRST BOARD OF DiRECTORS OF RCA

\begin{tabular}{|ll|}
\hline \multicolumn{1}{|c|}{ Position } & \multicolumn{1}{c|}{ Official } \\
Chairman & Mr. Owen D. Young \\
President & Mr. Edward J. Nally \\
General Counsel & Honourable John W. Griggs \\
Commercial Manager & Mr. David Sarnoff \\
Secretary & Mr. Charles J. Ross \\
Treasurer & Mr. George S. De Sousa \\
Assistant Secretary & Mr. Lewis MacConnach \\
Assistant Treasurer & Mrs. Marian H. Payne \\
\hline
\end{tabular}

On January $1^{\text {st }}, 1923$, Nally resigned the presidency when he was elected as the first Managing Director of International Relations of RCA. At this point, a discrepancy should be underlined in relation to other writers' opinion such as Sobel, who states that Nally then seemed an inappropriate choice for the firm, due to his extensive experience but only focused on wireless instead of broadcasting business and sales management. [8] The truth is that Edward J. Nally was the natural leader and the authentic soul of RCA.

\section{THE END OF THE EMPIRE}

Scientific research became the major factor in RCA progress, achieving remarkable achievements in international communications, marine radio, broadcasting, radio receivers, all-electric radios, radiophotos, radio-phonograph, radiofacsimile, network broadcasting, overseas broadcasting, shortwave reception, electronic television, microphones, radio relays, ultra-short wave equipment, electron tubes, miniaturization, NBC symphony, electron microscope, radar, television broadcasting, colour television, FM broadcasting, radiothermics, airbone television, teleran, shoran, snooperscope and sniperscope, ultrafax, atomic energy and electronics, transistors, community television, UHF television, electronic beverage inspection, electronics in medicine, colour corrector, electronic computers, military and space electronics, satellite communications etc. [9], [10], [11].

In 1986 RCA was definitely taken over by GE for $\$ 66.50$ per share, a total amount of $\$ 6.28$ billion in cash, and the RCA conglomerate began its liquidation by progressively selling several subsidiary companies such as RCA Laboratories Division, RCA Communications, Radiomarine Corporation of America, RCA Manufacturing Corporation, RCA Victor Corporation of America, RCA Records, RCA Radiotron,
General Motors Radio Corporation, National Broadcasting Company, etc.

In 1987 GE sold RCA's consumer-electronics manufacturing operations to French Thomson Inc. and the RCA trademark is nowadays licensed to third parties for products descended from the original RCA Corporation. [12]

\section{CONCLUSION}

While the original pioneers in radio stressed its value for international communications purposes, broadcasting opened an entirely new world across the globe.

The US Government put its greatest efforts into controlling an American private radio monopoly with the Secretary Josephus Daniels as the major US Navy involved celebrity, Edward J. Nally as the major commercial beneficiary, who perfectly designed the RCA and all its subsidiary branches, leaving afterwards his huge legacy to David Sarnoff, whose outstanding business management allowed the major development of the biggest communications corporation ever seen in the United States of America. In fact, Washington and Wall Street collaborated to create an international telecommunications entity designed to be America's chosen instrument in this industry worldwide.

\section{ACKNOWLEDGEMENT}

The authors wish to acknowledge the assistance and support of the HISTELCON, the IEEE and the UPM. Part of the research for this paper was conducted in 2008 when one of the authors, Alejandro Casasempere, was the IEEE Life fellow Intern at the IEEE History Center.

\section{REFERENCES}

[1] Gleason Leonard Archer, "History of Radio to 1926". New York, NY, USA. 1938.

[2] House Report $1273,73^{\text {rd }}$ Congress, $2^{\text {nd }}$ Session, "Preliminary Report on Communication Companies". April $18^{\text {th }}, 1934$.

[3] Princeton University, AEFG - CRIC report. "Edward Julian Nally Papers". Department of Rare Books and Special Collections, Princeton University Library. February $3^{\text {rd }} 1942$.

[4] Rear Admiral W. H. G. Bullard, USN, "Some Facts Connected with the Past and Present Radio Situation in the United States". United States Naval Institute Proceedings. October 1923.

[5] Princeton University. Handwritten first release draft of news about E. J. Nally's connection with wireless. "Edward Julian Nally Papers". Department of Rare Books and Special Collections, Princeton University Library. October $1^{\text {st }}, 1913$.

[6] Idem, E. J. Nally's handwritten note..November $28^{\text {th }}, 1942$.

[7] Idem, First Board of Directors of RCA...December $3^{\text {rd }}, 1919$.

[8] Robert Sobel, "RCA". New York, NY, USA. 1986.

[9] George H. Clark, "Radioana Collection". The Lemelson Center, Smithsonian Institution.

[10] RCA, "33 Years of Pioneering and Progress". 1953.

[11] Sarnoff Corporation, "Inventing the Future. 60 Years of Innovation at Sarnoff'. Princeton, NJ, USA. 2006.

[12] Radio Corporation of America. http://home.rca.com 